\title{
The Importance of Embouchure Technique on Flute Major Course in Universitas Negeri Surabaya
}

\author{
Heri Murbiyantoro, ${ }^{1, *}$ Moh. Sarjoko ${ }^{1}$ Raden Roro Maha Kalyana Mitta Anggoro²
}

\author{
${ }^{1,2}$ Music Study Program, Faculty of Language and Arts, Universitas Negeri Surabaya \\ *Corresponding author. Email: herimurbiantoro@unesa.ac.id
}

\begin{abstract}
This paper discusses the importance of the embouchure technique in Indria Level (basic level) Flute Major Course, in Music Study Program, Universitas Negeri Surabaya. The purpose is students become formed and accustomed to playing flute with proper basic posture. Later, it facilitates practicing and deepening skills in the following semesters. If students have qualified skills, then the goal of the university to produce graduates with applied skills character (as one of the human characters of 5.0 society) can be achieved. This study uses a descriptive-qualitative method with a pedagogic approach. Observations were made on the practicing process of each student, especially the formation of embouchure postures on the flute. Based on observations during the Indria level flute course process, it shows that students who can apply the posture of the flute in a detailed and precise manner, the components of flute playing regarding breathing techniques and tone production can also be supported. In conclusion, the embouchure technique is important to be understood and trained regularly by Major Flute students. It is the basic foundation to form tonality and intonation characters in flute playing, which will also affect the perfection of the performance of each etude or repertoire played.
\end{abstract}

Keywords: Music, Flute, Embouchure, Technique

\section{INTRODUCTION}

Nowadays, the world is being prepared to enter the era of 5.0 Society. The Japanese government initiated the 5.0 Society era in 2019 , which was initiated to anticipate the disruptive turmoil due to the 4.0 industrial revolution. It caused complex and ambiguous uncertainty, which was feared that the invasion could erode the values of human character that have been maintained so far. As stated by Dwi Conscience, S.KM., M.Si, the Analyst for the Implementation of the Education Curriculum of the Directorate of Elementary Schools, on February 3, 2021, she stated that in facing the era of super-smart society (5.0 society), two things need to be done, namely adaptation and competence [1]. Each individual is expected to have character as an adaptive and collaborative human resource and to have applied skill competencies in terms of the skills that can be applied in real terms to the community's needs. Especially in the world of education; in addition to optimizing not only cognitive competencies but also skill competencies to be the focus of attention, with the hope that it will make individuals have high competitiveness. Furthermore, the more complex and applicable the skills possessed, the more that individual will stand out and do more in the society world, which is full of creative and collaborative industry works. Thus, current educational institutions, from elementary education to university levels, are required to foster and produce individuals to have qualifications as 5.0 society person.

University as the spearhead of educational institutions also has a big responsibility to produce individuals with the character of 5.0 society; who are superior in cognitive and have skills that the needs of society can absorb. As stated by Maarif [2], the development of the performing arts today has been oriented to the problems of public taste and modernization problems. In line with this, Elfachmi in Izzah, Pradoko, and Syukur [3] also states that education today is one of the most essential needs for human life, which to obtain knowledge, whether in the school setting, or informally through the home, community, and environment. This is also the concern of the Music Study Program, Faculty of Language and Arts, Universitas Negeri Surabaya, as an institution that based on skills competency as its main concern. There are several selected musical instrument skill divisions facilitated by the Music Study Program, Faculty of Language and Arts, Universitas Negeri Surabaya, one of which is the flute division. The flute division in the lecture process strives for a balance of attention to theoretical material as well as practical material. I line with the character of 5.0 society; this paper also focuses on forming flute playing skills.

The flute instrument at the Music Study Program, Faculty of Language and Arts, Universitas Negeri Surabaya is taken in four semesters, starting 
from the Indria Level (as the basic level), Muda Level, Madya Level, to the Utama Level. As a foundation or basic step in forming skills to play a flute instrument, the Indria Level has an important role here. Some of the critical points in the Indria Level course, namely: (1) Techniques for tools assembling, (2) Postures of holding tools, (3) Breathing techniques, and (4) Embouchure techniques. Embouchure is a vital thing in the learning process at the Indria level. Lecturers have a big role in guiding and supervising the students' practice, especially in terms of paying attention to embouchure. Embouchure as a determinant of the tone producing of the flute can be produced precisely and optimally. In the Indria (basic) Level of flute course at the Music Study Program, Universitas Negeri Surabaya, students often have problems in placing positions or postures in applying the flute embouchure. Of course, the position or posture of the lips that are not appropriate will result in the formation of the flute tone producing itself. As explained earlier, that embouchure is an important thing that is one of the determinants and success factors of the process in practicing flute, especially for students of the Music Study program, Universitas Negeri Surabaya. Therefore, this paper discusses the importance of the embouchure technique in the lectures process of Indria Level (flute major). Thus, students become accustomed to playing flute with proper basic posture; in the long term, it can facilitate practicing and deepening skills in the following semesters. If students have qualified skills, then the goal of a university to produce graduates with applied skills character (as one of the human characters of 5.0 society) can be achieved. In addition, this research is expected to provide further confirmation to the wider community, both as flute practitioners or students who study flute instruments, regarding the important embouchure postures and need to be a constant concern in flute playing.

\section{METHOD}

This study uses a descriptive-qualitative method, with a pedagogic approach [4]. The pedagogic approach itself was determined because it was used to observe the Indria Level (Flute Major) learning process, especially in the process of practicing the embouchure technique. The qualitative research method was chosen because the focus discussed in this study intends to describe or explain the object to be studied. Data collection techniques through observations during the lecture process of the Indria Level (flute major). One of the theories that is used as a reference or analytical tool in this study is the theory of flute playing techniques by Jennifer Cluff. Cluff is a flute pedagogist who emphasizes 3 (three) things in playing flute, namely: (1) calmness, (2) flexibility, and (3) balance. As a teacher, Jennifer Cluff has a passion for anyone who wants to learn the flute. By becoming a teacher, Cluff believes that she can transmit the flute methods she developed [5]. Calmness, flexibility and balance; as the basic idea of Jennifer Cluff regarding the posture of flute playing, is one of the basis for the researcher's analysis of learning process of the Flute Major students, Music Study Program, Faculty of Language and Arts, Universitas Negeri Surabaya.

\section{RESULTS AND DISCUSSION}

\subsection{Flute Musical Instrument}

As it is known that flute, one of the woodwind family, originates from Europe. It was the oldest among the known instruments all over the world. Therefore, flute performance and constant innovation and transformation history is long in human society [6]. Flute is a woodwind instrument consisting of three main parts: the head joint, middle joint, and foot joint. Here's an overview of the musical flute parts:

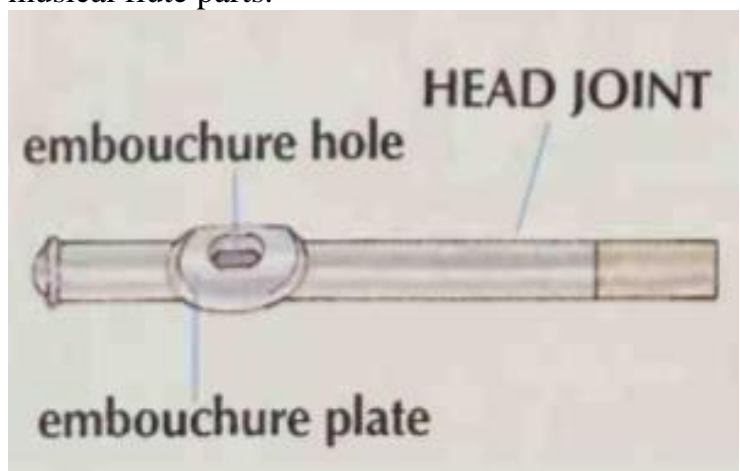

Figure 1 Flute Head Joint [7]

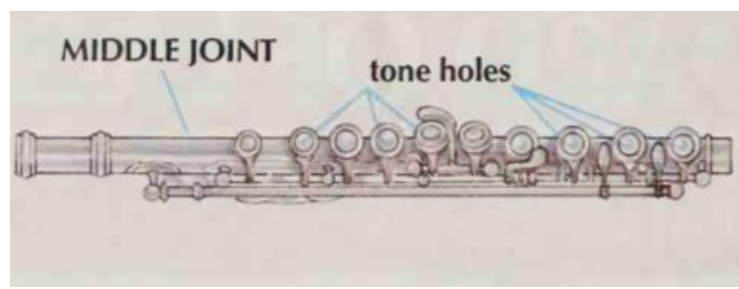

Figure 2 Flute Middle Joint [7]

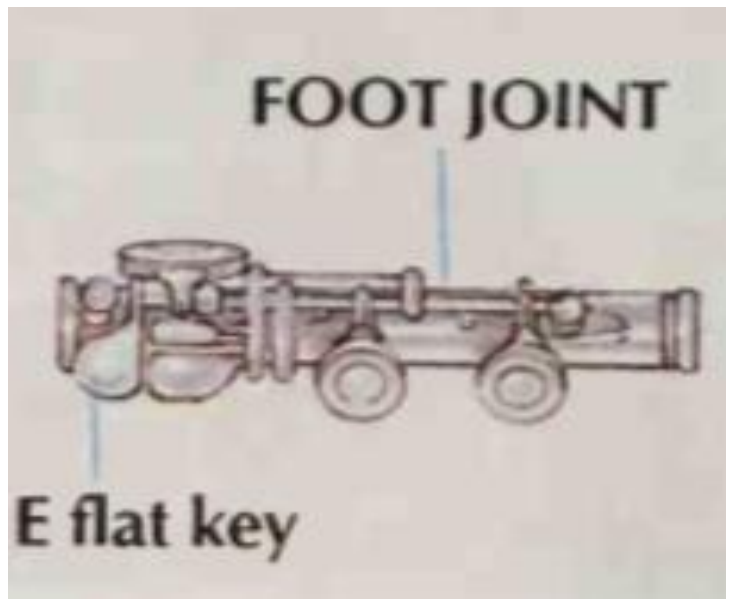

Figure 3 Flute Foot Joint [7] 
The Indria Level (flute major) consists of several aspects of learning, including: (1) Tool assembly technique, (2) Tool holding posture, (3) Breathing technique, and (4) Embouchure technique. As stated at the beginning, the focus of this paper is on the embouchure technique.

\subsection{Embouchure}

It is said that the domain of music education and the music industry move dynamically in an increasing competitive and promising direction [8]. The same with lectures process at the Music Study Program, Faculty of Language and Arts, Universitas Negeri Surabaya. Fundamentally, the sound of the flute is triggered by the air blown from the mouth into the mouthpiece, which is modified according to the coordination of fingering, embouchure, volume and the speed of the blown air stream tonguing movements [9], [10]. Developing a resonant and beautiful tone is one of the essential accomplishments to which all the flutists of all levels aspire. In fact, many tone instructional methods and tonal concepts have been prevalent worldwide since Quantz's time, which was 1697 1773 [10]. In line with this, instructional flute books and methods provide less information on how to prevent several problems occuring in flute playing [11]. One of them is about the embouchure technique. The players have to do many exercises to realize the coherence of respiration and breathing od mouth, nose, chest, and abdomen, which demands the flutist to coordinate the breathing while playing the instrument [12].

Embouchure is a way of blowing on woodwind instruments, especially on flutes. In every flute playing, embouchure is a fundamental part and must be known by every flute player [13]. Karetji also stated that every flute playing that applies the embouchure technique will produce a different sound. Embouchure posture for a flute player who is learning the Indria level, namely by attaching the lip line to the head joint of the flute, precisely in the tone hole. At the same time, the player will take a deep breath, then exhale like reciting the word 'pooh'. Generally, flute players who are new to playing flute instruments will train to form the right embouchure posture by only holding the head joint. Applying a good embouchure technique will make a very large contribution to airspeed control and give a certain sensitivity to the pitch. Louke in [13] says that the successful execution of this Technique requires accurate control of the flautist's air speed. Therefore, it can contribute towards increasing the flautist's air speed control, improving the embouchure position, and assisting in developing a greater sensitivity to pitch perception. It means that the embouchure is very important. However, in reality, many flute players ignore the correct way of blowing, even though the air being blown will greatly affect the color and intonation produced. Based on the results of observations done in the Indria Level (flute major) class, it turns out that most students are still unable or need more effort to be able to form precise embouchure postures. They also understand that the right embouchure technique is essential for a flute player. The reason is that the embouchure's function is to form a good sound color and help the flute player play with the appropriate intonation.

\subsection{Embouchure Technique Training for Students of Indria Level (Flute Major)}

As in the application of other woodwind instruments, they played flute and paid attention to basic technical details. Bastani Nezhad [14] stated that the techniques allow a pure and resonant sound, enabling performers to clearly differentiate between the low, middle, and high registers. It is the same with the lectures process on the Indria Level (Flute Major). At the Indria level, the main focus of the lecture material is on the formation of posture and the application of proper basic techniques, one of which is practicing precise embouchure techniques. There are several stages practicing the flute, including learning books from all over the world, one of which is described by Wye [15]. Trevor Wye advises practicing embouchure on the flute, including putting the flute down and taking a big breath without raising the shoulders. The stomach should expand, followed by the chest. If students have any difficulty doing this, they may sit in an upright chair and hold onto the seat. Then, take another breath that this time, the stomach should expand, do in repeat. The students may also pay attention about some things that they shouldn't do, for example: (1) Do not end the notation with the tongue, (2) Do not push the flute hard against the mouth in order to stop it slipping down; the student may tuck the left hand first finger a little under the flute. If the flute is slippery, glue some paper on where the first finger should go, but keep the left elbow down. (3) The students have to keep their shoulders down while playing and while taking a breath. (4) Do not allow the flute to be supported on a flat right-hand thumb. (5) Do not practice with the flute on a table. The students have to support it by using picture hooks and paper clips, or pop it up on the inside of the flute case if they do not have any music stands

In line with what Trevor Wye said, Glynn in "The Basic Band Book - Flute" also added that the crucial thing in practicing the flute's embouchure is to build lung stamina as breath support when playing the flute. Glynn provides several steps to optimize lung stamina to practice flute playing, including (1) Breathe air in, like we are whispering the letter 'o', and (2) Breathe air out, like we are whispering the 
word 'toe'. The students need to do those things with excellent posture, use as much air as possible, sit up straight and tall, and keep their shoulders relaxed. Besides that, the students can also do the breathing exercise, by some of these options: (1) Breathe in for 4 counts, breathe air out for 4 counts, (2) Breathe in for 3 counts, breathe air out for 5 counts, (3) Breathe in for 2 counts, breathe air out for 6 counts, and (4) Breathe in for 1 count, breathe air out for 7 counts; or students may make up their own combinations. This is a picture that relates how to make a good embouchure in playing flute:

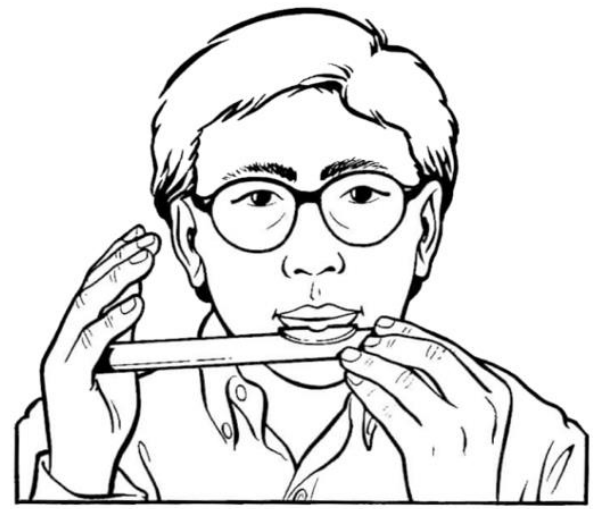

Figure 4 Embouchure Posture [16]

Combined with Wye and Glynn, Cluff also gave concepts that should be used as guidelines when practicing flute at a basic level, namely about calmness, flexibility, and balance. Calmness in the sense, how Music Study Program students must be very aware of the posture of the whole body, it must be relaxed, not stiff. Calmness in body posture (relaxed or not stiff) will positively impact how students inhale and exhale air in the embouchure hole. Flexibility, regarding body gestures, hands, fingers, and lips, must follow the needs of the air blow circulation (adjusting from the notation produced at that time); basically, playing music instrument is a total body movement to produce the sound production that is desired. Then, about balance. The balance that is meant here is how students are able to control the circulation of air that is inhaled and exhaled, in balance with the dynamics and tone color of the flute sound that they want from the music score that they practice. This collaboration of Wye, Glynn, and Cluff's practice concepts is the main reference for students of the Music Study Program, Universitas Negeri Surabaya in practicing flute embouchure at the Indria level (basic level). Indria Level Flute Course are held once a week, with a course duration of 150 minutes. Observations were made on the practice process of each student, especially in relation to the formation of embouchure postures on the flute. Based on observations during the Indria level flute course process, the following results were obtained:

\subsubsection{Breathing Technique}

Students have been able to control breathing effectively and efficiently. In a sense, they can adjust the air circulation needed, they adapt to the needs of the notation range and the required dynamics. This of course can happen because the student's embouchure posture has adequately been formed.

\subsubsection{Tone Production}

Through a continuous, detailed, and routine practicing process, students have produced the ideal color tone in the production of tones on a musical flute instrument. The tone color itself actually can be formed when a player has been able to apply the appropriate embouchure posture. Because the student has been able to produce tones optimally, it can be said that they have succeeded in bringing out the character or peculiarity of the flute instrument. The progress of the practicing carried out by students of the Music Study Program, Universitas Negeri Surabaya regarding the formation of the flute embouchure can be shown in this chart:

The Progress of the Embou chure Flute Practicing Process for Students of the Music Study Program, Universitas Negeri Surabaya

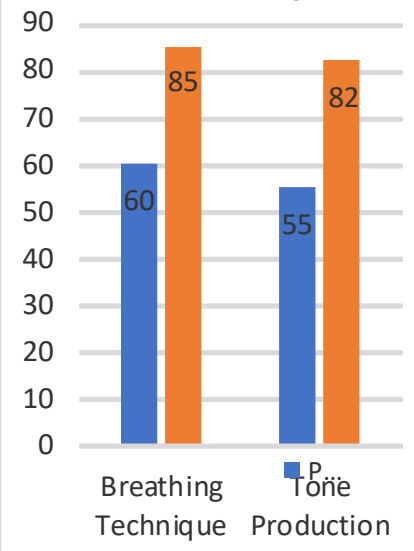

Figure 5 The Progress of the Flute Embouchure Practicing Process for Students of the Music Study Program, Universitas Negeri Surabaya

Referring to the Figure 5, it shows that students who are able to apply the posture of the flute in a detailed and precise manner, then directly, the components of flute playing regarding breathing techniques and tone production can also be supported.

\section{CONCLUSION}

Based on the explanation above, it can be concluded that the embouchure technique is an 
important thing that must be understood and trained regularly and continuously by Major Flute students. In every major flute lecture process, embouchure is a technique that is always monitored and observed from time to time. This is in line with what Karetji said, that embouchure is the basic foundation to form tonality and intonation characters in flute playing, which will also affect the perfection of the performance of each etude or repertoire played.

\section{ACKNOWLEDGMENTS}

This work was supported by Universitas Negeri Surabaya Research Grant.

\section{REFERENCES}

[1] Kemendikbud, "Menyiapkan Pendidik Profesional di Era Society 5.0," Directorat Jenderal PAUD, Dikdas dan Dikmen Kementerian Pendidikan, Kebudayaan, Riset dan Teknologi. pp. 1-2, 2021, [Online]. Available:

http://ditpsd.kemdikbud.go.id/artikel/detail/men yiapkan-pendidik-profesional-di-era-society-50.

[2] R. Maarif, “An Analysis of Perspective Value in Bamboo Flute Music Transformation: From Bamboo Instruments to Keyboard Instruments," in 1st International Conference on Education Social Sciences and Humanities (ICESSHum 2019), 2019, pp. 125-133.

[3] N. F. Izzah, A. M. S. Pradoko, and S. W. Syukur, "The Development of Android Application-Based E-Module Learning Media on the Makassar Flute Learning Material for Year 8 Junior High School Students," in 4th International Conference on Arts and Arts Education (ICAAE 2020), 2021, pp. 228-233.

[4] P. Dewantara and U. Utomo, "Strategi Khusus Pembelajaran Flute Kelas X Smk Negeri 2 Kasihan Bantul Yogyakarta," J. Seni Musik, vol. 8, no. 1, pp. 1-6, 2019.

[5] K. S. Cahyanti, "Praktik Flute Tingkat X di SMK N 2 Kasihan Bantul Ditinjau dari Teknik Merakit dan Posisi Bermain Flute Jennifer Cluff." Institut Seni Indonesia Yogyakarta, 2018.
[6] Q. Cheng, "Research on the Teaching Problems for Flute Performance Techniques," 2016.

[7] B. Pearson, C. Elledge, and J. Yarbrough, Standard of excellence. Neil A. Kjos Music Company, 1993.

[8] R. Ferdian, A. D. Putra, and F. Yuda, "Preparation of Learning Materials for Basic Flute Instrument Based on Locality and ABRSM Curriculum," in 1st International Conference on Lifelong Learning and Education for Sustainability (ICLLES 2019), 2020, pp. 145-150.

[9] A. Azizol, "Sonic Exploration of Alto Recorder for Nadi Bumi: Applied Research in Contemporary Classical Music Composition," Malaysian J. Music, vol. 6, no. 2, pp. 71-93, 2017.

[10] A. BastaniNezhad, "Primal Sound and its Application in Tone Pedagogy of Western Classical Flute," Malaysian J. Music, vol. 2, no. 1, pp. 10-29, 2013.

[11] K. A. Lonsdale and L. Laakso, "Preventing flute playing-related musculoskeletal disorders: applying ergonomic principles in individual and ensemble settings," Malaysian J. Music, vol. 3, no. 1, pp. 67-81, 2014.

[12] Z. Song, "On Development and Change of Cucurbit Flute Music of the Dai Ethnic Group in Yunnan," in 2016 International Conference on Education, Sports, Arts and Management Engineering, 2016, pp. 251-255.

[13] R. Karetji, "Kajian metode pengajaran peniupan embouchure pada pembelajaran flute pada tingkat intermediate sekolah x." Universitas Pelita Harapan, 2020.

[14] A. B. Nezhad, "Iranian Classical Ney: pedagogy and performance," Malaysian $J$. Music, vol. 3, no. 1, pp. 48-66, 2014.

[15] T. Wye, Trevor Wye Practice Book For The Flute: Book 1-Tone. Novello \& Co Ltd., 2013.

[16] Glynn, "Flute Lesson 1 - The Basic Band Book," 2014. . 